\title{
PENINGKATAN PEMAHAMAN TENTANG METAMORFOSIS MELALUI MEDIA GAMBAR SERI DI KELOMPOK B TK NEGERI PEMBINA KOTA TASIKMALAYA
}

\author{
Taopik Rahman ${ }^{1}$, Edi Hendri Mulyana ${ }^{2}$, Sri Wendah ${ }^{3}$ \\ ${ }^{1}$ Program Studi PGPAUD UPI Kampus Tasikmalaya \\ ${ }^{2}$ Program Studi PGPAUD UPI Kampus Tasikmalaya \\ ${ }^{3}$ Program Studi PGPAUD UPI Kampus Tasikmalaya
}

Email : opik@upi.edu

(Received: November 2018; Accepted: November 2018; Published: Desember 2018)

\begin{abstract}
This research uses classroom action research method (PTK) model Kemmis and MC. Tanggart, the research was conducted based on the findings of the problem of understanding about metamorphosis in B TK Negeri Pembina, this is because in learning only use oral course in the introduction or explanation does not use supporting media that will facilitate the child understand about metamorphosis. One way that researchers can use in improving the understanding of metamorphosis is by using media and media that is used the series image media. Serial drawings are drawings that have a continuous arrangement. The purpose of this research is to get a picture about the improvement of understanding about metamorphosis through serial drawing media. Subjects in this study that is a child group B TK Negeri Pembina Tasikmalaya City in the even semester of the academic year 2018 which amounted to 8 children who are considered difficult children understand metamorphosis and researchers act as classroom teachers. The data collection techniques used are observation, interview and documentation. This research was conducted in 3 cycles and the result of the research that has been done shows the improvement of the teacher's ability in planning the learning, the ability of the teacher in managing the learning, the ability of the teacher in the use of drawing media series, the children's understanding about the metamorphosis and the children activity when engaging the drawing media series.
\end{abstract}

Keywords: Early Childhod, metamorphosis, series image media

\begin{abstract}
ABSTRAK
Penelitian ini menggunakan metode penelitian tindakan kelas (PTK) model Kemmis dan MC. Tanggart, penelitian dilakukan berdasarkan temuan adanya masalah pemahaman tentang metamorfosis dikelmpok B TK Negeri Pembina, hal ini dikarenakan dalam pembelajaran hanya menggunakan lisan saja dalam pengenalan atau penjelasan tidak menggunakan media pendukung yang akan memudahkan anak memahami tentang metamorfosis. Salah satu cara yang dapat digunakan peneliti dalam meningkatkan pemahaman tentang metamorfosis yaitu dengan menggunakan media dan media yang digunakan yaitu media gambar seri. Gambar seri yaitu gambar yang mempunyai susunan yang berkesinambunga. Tujuan dari penelitian ini yaitu memperoleh gambaran tentang peningkatan pemahaman tentang metamorfosis melalui media gambar seri. Subjek dalam penelitian ini yaitu anak kelompok B TK Negeri Pembina Kota Tasikmalaya pada semester genap tahun ajaran 2018 yang berjumlah 8 orang anak yang dianggap anak yang sulit memahami metamorfosis dan peneliti bertindak sebagai guru kelas. Adapun teknik pengumpulan data yang digunakan adalah observasi, wawancara dan sokumentasi. Penelitian ini dilaksanakan dalam 3 siklus dan hasil penelitian yang telah dilaksanakan menunjukan peningkatan pada kemampuan guru dalam merencanakan pembelajaran, kemampuan guru dalam mengelola pembelajaran, kemampuan guru dalam penggunaan media gambar seri, pemahaman anak tentang metamorfosis dan aktivitas anak saat terlibat media gambar seri.

Kata kunci : anak usia dini, metamorfosis, media gambar seri
\end{abstract}




\section{PENDAHULUAN}

Undang-undang No. 20 Tahun 2003 tentang Sistem Pendidikan Nasional "Pendidikan anak usia dini (PAUD) adalah suatu upaya untuk pembinaan yang ditujukan kepada anak sejak lahir sampai usia 6 tahun yang dilakukan melalui pemberian rangsangan pendidikan untuk membantu pertumbuhan dan perkembangan jasmani dan rohani agar anak memiliki kesiapan dalam memasuki pendidikan lanjut."

Pendidikan anak usia dini untuk mempersiapkan anak ke jenjang selanjutnya dengan memperkenalkan berbagai pengetahuan, sikap, prilaku, keterampilan dan intelektual. Pendidikan kepada anak usia dini harus sesuai dengan perkembangan, kemampuan dan minat anak.

Aspek perkembangan anak pada usia 5-6 tahun mengalami banyak perubahan, sehingga banyak hal yang layak diberikan pada usia tersebut. Anak senang melakukan berbagai eksplorasi terhadap segala sesuatu. Pada usia ini juga rasa ingin tahu anak sangat tinggi, dengan begitu tugas guru memfasilitasi anak berbagai pengetahuan yang dibutuhkan oleh anak untuk tumbuh kembangnya. Salah satu aspek perkembangan pada usia 5-6 tahun juga sangat menekankan terhadap lingkungan karena karakteristik anak usia ini lebih kepada apa yang dilihat didengar dan dirasakan. Seperti dijelaskan dalam Sujiono (2013, hlm. 161) kemampuan perseptual kognitif anak usia 5-6 tahun salah satunya yaitu "Menunjukan minat terhadap alam, pengetahuan, binatang, waktu dan bagaimana benda bekerja." Sebagaimana dijelaskan dalam Lampian I Peraturan Menteri Pendidikan dan Kebudayaan Republik Indonesia Nomor 146 Tahun 2014 tentang Kurikulum 2013 Pendidikan Anak Usia Dini salah satunya pada poin 3.8 yang berbunyi "mengenal lingkungan alam (hewan, tanaman, cuaca, tanah, air, batu-batuan, dll)" disini diartikan bahwa anak usia 5-6 tahun harus diberikan pengetahuan tentang lingkungan alam yang ada disekitar anak agar anak dapat bereksplorasi di lingkungannya. Diperjelas dalam indikator pencapaian perkembangan anak usia 5-6 tahun yang berbunyi “ Menceritakan perkembangbiakan mahluk hidup".

\section{Perkembangbiakan menurut KBBI} adalah hal-hal yang berhubungan dengan berkembang biak. Perkembangbiakan makhluk hidup berbagai macam, salah satunya disebut dengan metamorfosis. Panut (2006, hlm. 83) "Metamorfosis adalah proses perubahan bentuk dari larva menjadi dewasa." Metamorfosis adalah perubahan bentuk yang dapat dilihat secara langsung karena perubahan bentuk hewan yang bermetamorfosis sangat signifikan. Hewan yang bermetamorfosis di bagi dua yaitu metamorfosis sempurna dan metamorfosis tidak sempurna. Hewan yang disebut metamorfosis sempurna karena memiliki siklus yang lebih panjang dibandingkan dengan hewan yang bermetamorfosis tidak sempurna. Hewan yang bermetamorfosis sempurna diantaranya kupukupu, katak dan nyamuk. Pembelajaran pada 
anak usia dini tentang metamorfosis harus dapat disampaikan karena aspek perkembangan anak tentang perkembang biakan harus didapat oleh anak, karena indikator capaian perkembangan anak usia 5-6 tahun harus dapat tercapai dengan maksimal.

Berdasarkan pengamatan awal yang dilakukan peneliti di TK Negeri Pembina ditemukan permasalahan guru tentang penyampaian materi mengenai metamorfosis pada hewan. Permasalahan yang muncul yaitu anak tidak memahami apa yang dijelaskan oleh guru, hal ini ditunjukan dengan banyaknya anak yang tidak dapat menjawab pertanyaan guru ketika ditanya proses hewan yang bermetamorfosis. Hal ini terjadi karena proses pembelajaran yang dilakukan hanya dengan menggunakan ceramah tanpa menggunakan fasilitas pendukung yang membuat anak dapat memahami apa yang disampaikan oleh guru. Karena pembelajaran yang dilakukan kepada anak usia 5-6 tahun harus ada fasilitas yang mendukung agar memudahkan anak untuk memahami pembelajaran yang disampaikan, seperti yang dijelaskan dalam teori Piaget menurut Mara'at (2012, hlm. 47) "tahap preoperational usia anak 2-7 tahun, anak mulai merepresentasikan dunia dengan kata-kata dan gambar". Selain itu guru kelompok B di TK Negeri Pembina menggunakan metode ceramah karena kesulitan dalam mengajarkan metamorfosis secara langsung karena metamorfosis tidak dapat diperlihatkan secara langsung pada setiap tahapan perubahan bentuk karena setiap fasenya memerlukan jarak yang tidak memungkinkan dilihat oleh anak, dan media yang memberikan pemahaman tentang hewan yang bermetamorfosis atau fasilitas pendukung yang membantu guru dalam menjelaskan hewan yang bermetamorfosis tidak ada.

Media yang dapat dijadikan Menurut (Khadijah, 2015, hlm. 14) "media merupakan perantara yang dapat mempengaruhi sikap, nilai, emosi dan mampu membangkitkan minat anak dalam proses kegiatan pembelajaran, dan juga dapat membantu menggabungkan pengalaman belajar yang baru dengan sebelumnya." Bisa di artikan ketika guru menggunakan media dalam proses kegiatan pembelajaran, dapat memudahkan guru dalam menjelaskan materi yang ingin disampaikan dan dapat membuat anak mudah memahami apa yang dijelaskan oleh guru. Dengan begitu media sangat perlu dibutuhkan dalam pembelajaran anak usia dini. Sebagaimana ada dala artikel penelitian yang berjudul "Meningkatkan Proses dan Hasil Belajar Model Inquiri dalam Pembelajaran Daur Hidup" Marsudi (2013). Didalamnya dijelaskan daur hidup yang dijelaskan disana yaitu metamorfosis. Pembelajaran metamorfosis menggunakan media gambar dapat meningkatkan hasil belajar anak. Dengan begitu media gambar dapat menjadi alternatif untuk meningkatkan pemahaman anak tentang metamorfosis. Media gambar yang digunakan oleh peneliti yaitu media gambar berseri, karena sesuai dengan karakteristik 
metamorfosis yaitu memiliki urutan atau tahapan yang berkesinambungan.

Dengan begitu media sebagai pendukung dalam pembelajaran khususnya dalam pembelajaran tentang metamorfosis sangat penting, dilihat dari perkembangan anak usia 5-6 tahun yang tidak dapat berfikir secara abstrak apabila pembelajaran menggunakan metode ceramah tanpa media sebagai penunjang. Setelah melakukan refleksi awal dengan guru kelas, maka telah disepakati sebagai alternatif media pembelajaran untuk meningkatkan pemahaman tentang metamorfosis di kelompok B TK Negeri Pembina adalah dengan menggunakan media gambar seri.

Menurut Madyawati (2016, hlm,208) "Media gambar seri yaitu urutan gambar yang mengikuti suatu percakapan dalam hal memperkenalkan atau menyajikan arti yang terdapat pada gambar." Penggunaan media gambar berseri dapat menjadi alternatif untuk memfasilitasi pemahaman siswa tentang hewan yang bermetamorfosis, karena struktur gambar berseri mempunyai urutan yang dapat dipergunakan sebagai urutan perubahan hewan yang bermetamorfosis. Dengan demikian berdasarkan kesepakatan guru dan peneliti, penelitian ini menggunakan Penelitian Tindakan Kelas dengan judul penelitian : "Peningkatan Pemahaman tentang Metamorfosis melalui Media Gambar Seri di Kelompok B TK Negeri Pembina Kota Tasikmalaya."

\section{TINJAUAN PUSTAKA}

Menurut Sujiono (2013, hlm.6) "Anak usia dini adalah sosok individu yang sedang menjalani suatu proses perkembangan dengan pesat dan fundamental bagi kehidupan selanjutnya." Anak usia dini berada pada rentan usia 0-6 tahun, pada proses ini pertumbuhan dan perkembangan dalam berbagai aspek sedang mengalami masa yang cepat dalam rentang perkembangan hidup manusia. Catron dan Allen (dalam Sujiono, 2013, hlm. 62) mengemukakan bahwa “terdapat 6 aspek perkembangan anak usia dini yaitu kesadaran personal, kesehatan emosional, sosialisasi, komunikasi, kognisi dan keterampilan motorik..." keenam aspek yang disebutkan harus dikembangkan dengan optimal agar anak dapat melewati setiap fase perkembangannya dengan baik tanpa terlewat satupun.

Salah satu aspek perkembangan yang harus dioptimalkan yaitu kognitif. Kognitif dapat diartikan pengan pemahaman tentang pengetahuan yang didapat oleh anak atau kombinasi dari pengetahuan yang sudah diketahui oleh anak dan yang baru anak ketahui. Misalnya ketika anak mengetahui hewan yang berekor itu bernama anjing, ketika diperlihatkan kucing anak akan menganggap itu anjing. Akan tetapi ketika guru menjelaskan bahwa hewan yang berekor bukan hanya anjing, ada hewan yang lain seperti kucing. Dengan begitu anak paham bahwa yang berekor tidak hanya anjing ada hewan lain yang mempunyai ekor seperti kucing. 
Di dalam aspek kognitif juga dijelaskan juga tentang kebutuhan anak untuk secara aktif didalam lingkungan. Lingkungan yang dimaksud yaitu lingkungan yang berada didekat anak. Seperti yang dijelaskan dalam Permendikbud Tahun 2014 tentang Kurikulum 2013 Pendidikan Anak Usia Dini dalam kompetensi Dasar 4.8 yang berbunyi “ Menyajikan berbagai karya yang berhubungan dengan lingkungan alam (hewan, tana 7 cuaca, tanah, air, batu-batuan, dll) dalam bentuk gambar, bercerita, bernyanyi dan gerak tubuh" dan diperjelas dalam indikator pencapaian perkembangan anak usia 5-6 tahun yang berbunyi “ Menceritakan perkembangbiakan mahluk hidup".

Perkembangan mahluk hidup sangat luas apabila dibahas seluruhnya. Dalam perkembangan anak usia dini mempelajari perkembangbiakan mahluk hidup tidak seluruhnya dijelaskan secara rinci tetapi dijelaskan secara sederhana sehingga anak mudah memahami bagaimana proses perkembangan hidup hewan yang sering anakanak temui. Dengan begitu anak memperoleh pengetahuan yang seharusnya didapat tentang perkembangbiakan mahluk hidup.

Pemahaman menurut Kamus Besar Bahasa Indonesia adalah proses, cara, perbuatan memahami atau memhamkan. Sedangkan Panut (2006, hlm. 83) "Metamorfosis adalah proses perubahan bentuk dari larva menjadi dewasa". Metamorfosis adalah suatu proses dimana hewan secara fisik mengalami perkembangan dan pertumbuhan setelah menetas. Jadi pemahaman tentang metamorfosis yaitu cara memahami perubahan bentuk yang dialami hewan. Dimana hewan mengalami perubahan bentuk dari telur hingga dewasa. Ada dua jenis metamorfosis yaitu metamorfosis sempurna dan metamorfosis tidak sempurna.

Metamorfosis tidak sempurna merupakan siklus perubahan menjadi serangga setelah berubah dari bentuk nimfa. Metamorfosis tidak sempurna umumnya terjadi pada hewan jenis serangga seperti capung, belalang, jangkrik dan lainnya. Sedangkan metamorfosis sempurna mengalami tahapan yang lebih panjang. Metamorfosis sempurna hanya dimiliki oleh katak, kupu-kupu dan nyamuk.

Metamorfosis kupu-kupu memiliki fase yang berurutan. Farndon dan Kirkwoond (2011, hlm. 27) mengemukakan tahapan metamorfosis kupu-kupu :

a. Kupu-kupu betina bertelur diranting pohon yang cocok untuk meletakan telurnya.

b. Setelah kurang lebih 2 minggu sampai 1 bulan telur menetas menjadi ulat. Lalu ulat memakan pucuk tumbuhan yang masih lunak. Ulat mengalami 5 kali pergantian kulit.

c. Lalu ulat memintal dirinya menjadi kepompong. Periode menjadi kepompong selama 2 minggu sampai beberapa bulan.

d. lama-lama ia keluar menjadi menjadi kupukupu.

Panut (2006, hlm. 85)"Katak termasuk hewan amfibi. Ampibi artinya dua kehidupan"Katak adalah hewan yang hidup di darat dan di air. 
Katak dalam melanjutkan generasinya, melakukan proses metamorfosis, yaitu perubahan bentuk dan fungsi organ tubuh. Perubahan bentuk dan fungsi ini terjadi sangat mencolok di setiap tahapannya. Itulah sebabnya mengapa sehingga metamorfosis pada katak disebut dengan metamorfosis sempurna. Tahapan metamorfosis katak yaitu : katak betina bertelur didalam air dan telur-telur itu ditutupi oleh jelly agar terlindungi sehingga seolah-olah berhubungan satu dengan yang lainnya. Setelah beberapa saat telur menetas menjadi kecebong yang bentuknya menyerupai ikan tumbuh dan berkembang menjadi kecebong berkaki dua terus tumbuh menjadi kecebong berkaki empat. Lalu setelah itu menjadi katak muda, katak muda ini masih mempunyai ekor seperti kecebong, setelah beberapa hari ekor kecebong menyusut dan hilang. Dan terakhir menjadi katak dewasa.

Nyamuk dapat ditemukan dimana-mana. Nyamuk dianggap hama oleh manusia karena sangat merugikan manusia, bahkan dapat menularkan penyakit pada manusia ketika digigit oleh nyamuk tertentu. Nyamuk bersarang ditempat yang kotor. Devi dan Anggraeni (2008, hlm. 59) mengemukaan tahapan metamorfosis nyamuk adalah "nyamuk betina bertelur di air, kemudian telur menetas menjadi jentikjentik atau larva tingkat I. Larva tingkat I akan tumbuh dan berkembang menjadi larva tingkat II atau pupa. Kemudian dari pupa ini akan keluar nyamuk. Mulai dari telur sampai pupa semuanya berada di air". Telur nyamuk bertelur di air yang tergenang, telur nyamuk berjumlah sangat banyak lebih dari 100 butir.

Menurut Madyawati (2016, hlm,208) "Media gambar seri yaitu urutan gambar yang mengikuti suatu percakapan dalam hal memperkenalkan atau menyajikan arti yang terdapat pada gambar." Dikatakan gambar seri karena gambar satu dengan gambar yang lain memiliki hubungan keruntutan peristiwa, dapat dikatakan pula gambar seri adalah rangkaian gambar yang menceritakan suatu peristiwa yang beruntut dari gambar satu dengan gambar lainnya. Gambar seri merupakan serangkaian gambar yang tersusun secara berurutan sehingga dapat membentuk sebuah cerita yang runtut.

\section{METODE}

Penelitian ini dilakukan melalui kerja kolaboratif antara guru dan peneliti. Secara kolaboratif disini artinya guru disini sebagai pihak yang melakukan tindakan sedangkan peneliti disini sebagai pengamat. Model PTK yang digunakan dalam penelitian ini yaitu model Kemmis \& Taggart. Penelitian tindakan kelas ini dilaksanakan di kelompok B TK N Pembina Kota Tasikmalaya. Pemilihan TK N Pembina. Subjek penelitian ini adalah sebanyak 8 orang anak di kelompok B TK Negeri Pembina Kota Tasikmalaya dalam rentang usia 5-6 tahun yang dianggap kurang dalam memahami tentang metamorfosis. Variabel penelitiannya yaitu, variabel proses yaitu penggunaan media gambar seri. variabel hasil yaitu peningkatan pemahaman tenang metamorfosis. Penelitian ini menggunakan instrumen lembar observasi dan wawancara. Data yang diperlukan dalam penelitian ini, yaitu : 
1. Data tetang pemahaman anak tentang metamorfosis di kelompok B TK Negeri Pembina Kota Tasikmalaya

2. Data tentang pelaksanaan pembelajaran pada saat tahap tindakan.

Adapun sumber data dalam penelitian ini, yaitu :

1. Kepustakaan, yaitu mengumpulkan data dan informasi dari buku, jurnal dan artikel

2. Lapangan, yaitu pengumpulan data dan informasi dilakukan langsung dari lokasi penelitian. Sumber data ini meliputi guru, siswa, dokumen sekolah dan lainlainnya.

Teknik pengumpulan data yang digunakan untuk mengumpulkan data dalam penelitian ini menggunakan teknik lembar observasi, wawancara dan dokumentasi.

Pengolahan data dalam penelitian ini adalah amalisis deskriptif kuantitatif dan kualitatif dengan kerangka analisis sebagai berikut :

1. Pengumpulan data hasil penitian tindakan kelas tentang pembelajaran peningkatan pemahaman tentang metamorfosus melalui penggunaan media gambar seri.

2. Pengelompokan data yaitu data tentang kinerja anak, kinerja guru dan peningkatan pemahaman anak tentang metamorfosis melalui penggunaan media gambar seri

3. Interpretasi dan refleksi data berdasarkan tingkat pencapaian misalnya belum berkembang, mulai berkembang, berkembang sesuai harapan dan berkembang sangat baik.
4. Rekomendasi dan tindak lanjut ditentukan berdasarkan hasil peningkatan pemahaman tentang metamorfosis melalui penggunaan media gambar seri.

Kriteria keberhasilan harus mengalami peningkatan, baik pada kemampuan guru maupun anak dalam melaksanakan pembelajaran peningkatan pemahaman anak tentang metamorfosis melalui media gambar seri.

Prosedur penelitian yang digunakan yaitu : perencanaan, pelaksaan, pengamatan dan refleksi.

\section{HASIL DAN PEMBAHASAN}

Penelitian tindakan kelas yang dilakukan pneliti ini terdiri dari tiga siklus, siklus I dilaksnakan pada tanggal 24 April 2018, siklus II dilaksanakan pada tanggal 30 April 2018 dan siklus III dilaksanakan pada tanggal 04 Mei 2018. Penelitian ini meningkatkan pemahaman tentang metamorfosis melalui media gambar seri di kelompok B TK Negeri Pembina Kota Tasikmalaya.

1 Kemampuan Guru dalam Merancang Pembelajaran

Perencanaan pembelajaran pada Penelitian Tindakan Kelas terdiri dari tiga siklus perencanaan pembelajaran. Pada tiga siklus penelitian tindakan kelas ini, peningkatan kinerja guru dalam merancang pembelajaran adalah : siklus I kinerja guru dalam merancang pembelajaran adalah 10,66 dengan rata-rata 
2,66 dan kriteria keberhasilan Baik. Meskipun sudah mencapai kriteria baik, tetapi masih ada kelemahan pada siklus I yaitu dalam mengembangkan tema / subtema, dalam merencanakan pengelolaan kegiatan dan menggunakan Bahasa tulis yang baik dan benar. Pada siklus II mengalami peningkatan dengan jumlah 12,33 rata-rata 3,04 dan kriteria keberhasilan sangat baik. Namun masih ada kelemahan pada siklus II yaitu pada perencanaan pengelolaan kegiatan pada pemanfaatan media pembelajaran sesuai dengan bidang pengembangan. Kekurangan tersebut dapat diatasi oleh guru sehingga siklus III mengalami peningkatan kembali dengan jumlah 14,15 rata-rata 3,53 dan kriteria keberhasilan sangat baik. Peningkatan pada siklus II ke siklus II rentang 0,45, karena adanya persiapan dan perbaikan lebih matang dalam merencanakan pembelajaran (RPPH).

2. Kemampuan Guru dalam Proses Pembelajaran

Pelaksanaan pembelajaran peningkatan pemahaman tentang metamorfosis melalui media gammbar seri. Kemampuan peneliti dalam melaksanakan kegiatan pembelajaran pada siklus I dengan jumlah 7 rata-rata 2,33 dengan kriteria baik, ada beberapa yang harus diperbaiki yaitu dalam kegiatan mengelola pembelajaran awal, pemanfaatan sumber belajar / media pembelajaran, penilaian proses dan hasil belajar dana melakukan refleksi atau membuat rangkuman dengan melibatkan siswa. Pada siklus II kelemahan-kelemahan peneliti dalam pelaksanaan diperbaiki dan mengalami peningkatan dengan jumlah 9,13 rata-rata 3,04 dengan kriteria dangat baik. Pada siklus II masih terdapat kelemhan yaitu dalam melakukan refleksi atau membuat rangkuman dengan melibatkan siswa. Pada siklus III, kelemahan-kelemahan pada siklus II diperbaiki dengan adanya persiapan dan perbaikan yang lebih matang, kemampuan dalam melaksanakan kegiatan pembelajaran mengalami peningkatan menjadi jumlah 9,93 rata-rata 3,32 dengan kriteria sangat baik. Nampak bahwa peningkatan pada siklus II ke siklus III dengan rentang sebesar o,27.

Sedangkan kemampuan guru dalam pembelajaran menggunakan media gambar seri, pada siklus I sebesar 7,11 dengan kriteria baik. Namun demikian masih ada aspek yang belum dilaksanakan. Pada siklus II, kekurangan tersebut dapat dilaksanakan sehingga mengalami peningkatan sebesar 1,99 dan menjadi 9,1 dengan kriteria sangat baik. Namun pada siklus II masih terdapat kekurangan yaitu masih ada aspek yang belum terlaksana. Pada siklus III aspek yang belum terlaksana dapat dilaksanakan sehingga mengalami peningkatan menjadi 10 dengan kriteria sangat baik. Sehingga dapat dikatakan bahwa kemampuan guru dalam pembelajaran menggunakan media gambar seri pada siklus III dengan kriteria mencapai sangat baik.

3. Pemahaman tentang Metamorfosis 


\section{a. Perubahan Bentuk}

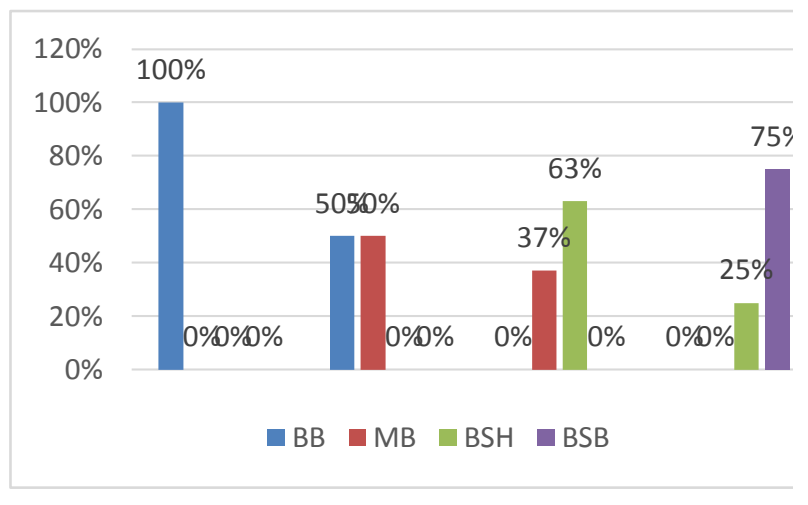

berdasarkan diagram dapat dilihat bahwa kriteria BB (Belum Berkembang) pada pra tindakan sebesar 100\% (8 orang anak), siklus I sebesar $50 \%$ (4 orang anak), siklus II dan siklus III tidak ada satupun kriteria BB (Belum Berkembang). Kriteria MB (Mulai Berkembang) siklus I 50\% (4 orang anak), siklus II 37\% (3 orang anak) dan siklus III tidak ada satupun kriteria MB (Mulai Berkembang). Kriteria BSH (Berkembang Sesuai Harapan) pada pratindakan dan siklus I tidak ada satupun kriteria BSH (Berkembang Sesuai Harapan), siklus II 63\% (5 orang anak)dan siklus III $25 \%$ (2 orang anak). Kriteria BSB (Berkembang Sangat Baik) pada pra tindakan, siklus I dan siklus II tidak ada satupun kriteria BSB (Berkembang Sangat Baik), siklus III 75\% (6 orang anak). Dari data tersebut pemahaman anak tentang metamorfosis dalam aspek perubahan bentuk mengalami peningkatan. b. Perubahan Fungsi

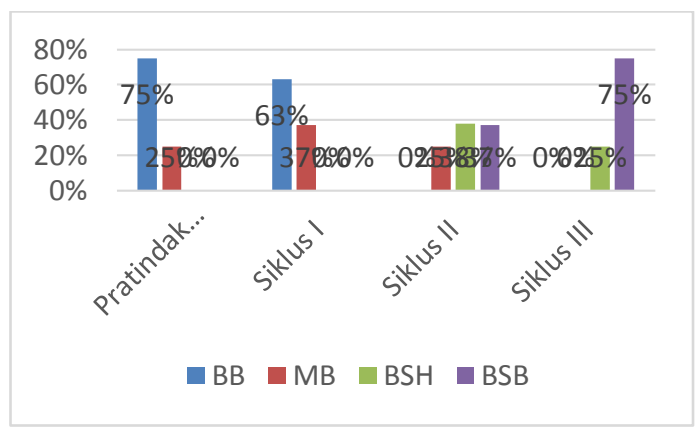

Dari gambar dapat dilihat bahwa kriteria BB

(Belum Berkembang) pada pra tindakan $75 \%$ (6 orang anak), siklus I 63\% (5 orang anak), siklus II dan siklus III tidak ada satupun kriteria BB (Belum Berkembang). Kriteria MB pada pra tindakan $25 \%$ (2 orang anak), pada siklus I 37\% (3 orang anak), pada siklus II $25 \%$ (2 orang anak), dan pada siklus III tidak ada satupun kriteria MB (Mulai Berkembang). Kriteria BSH pada pra tindakan dan siklus I tidak ada satupun kriteria BSH (Berkembang Sesuai Harapan), siklus II 38\% (3 orang anak) dan pada siklus III 25\% (2 orang anak). Kriteria BSB pada pra tindakan dan siklus I tidak ada satupun, siklus II 37\% (3 orang anak), pada siklus III 75\% (6 orang anak). Dari data diatas pemahaman anak tentang metamorfosis aspek perubahan fungsi mengalami peningkatan. Hal tersebut terlihat dari BB (Belum Berkembang) menjadi MB (Mulai Berkembang), dari MB (Mulai Berkembang) menjadi BSH (Berkembang Sesuai Harapan) dari BSH (Berkembang Sesuai Harapan) menjadi BSB (Berkembang Sangat Baik). 
c. Tahapan

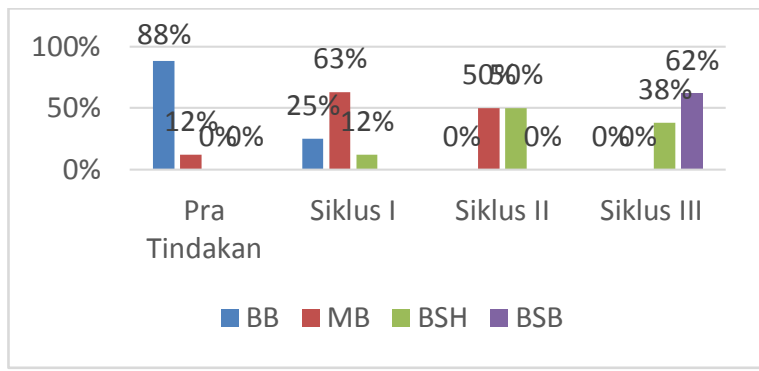

Berdasarkan gambar dapat dilihat bahwa kriteria BB (Belum Berkembang pada pra tindakan $88 \%$ (7 orang anak), siklus I 25\% (2 orang anak, siklus II dan siklus III tidak ada satupun kriteria BB (Belum Berkembang). Kriteria MB (Mulai Berkembang pada pra tindakan 12\% (1 orang anak), siklus I 63\% (5 orang anak), pada siklus II 50\% (4 orang anak), dan pada siklus III tidak ada satupun kriteria MB (Mulai Berkembang). Kriteria BSH (Berkembang Sesuai Harapan) pada pratindakan tidak ada satupun kriteria $\mathrm{BSH}$ (Berkembang Sesuai Harapan),siklus I 12\% (1 orang anak), siklus II 50\% (4 orang anak), siklus III 38\% (3 orang anak). Kriteria BSB (Berkembang Sangat Baik pada pra tindakan, siklus I, dan siklus II tidak ada satupun kriteria BSB (Berkembang Sangat Baik), siklus III $62 \%$ (5 orang anak). Dari data diatas pemahaman anak tentang metamorfosis mengalami peningkatan. Hal tersebut terlihat dari BB (Belum Berkembang) menjadi MB (Mulai Berkembang), dari MB (Mulai Berkembang) menjadi BSH (Berkembang Sesuai Harapan) dari BSH (Berkembang Sesuai Harapan) menjadi BSB (Berkembang Sangat Baik).

\section{Aktivitas Anak saat Terlibat Media Gambar} Seri

Aktivitas anak data terlibat media gambar seri terdiri dari tiga siklus disetiap siklus terdapat 3 aktivitas yang dikerjakan oleh anak. Peningkatan aktivitas anak saat terlibat media gambar seri dengan kegiatan yaitu mewarnai gambar metamorfosis, menarik garis sesuai pola, dan menempelkan perubahan bentuk metamorfosis sesuai dengan tahapannya. Pada siklus I kriteria BB (Belum Berkembang) 1 orang anak, kriteria MB (Mulai Berkembang) 7 orang anak, dan tidak ada kriteria BSH (Berkembang Sesuai Harapan) dan kriteria BSB (Berkembang Sangat Baik). Pada siklus II tidak ada satupun kriteria BB (Belum Berkembang) dan MB (Mulai Berkembang), kriteria BSH (Berkembang Sesuai Harapan) 5 orang anak, dan BSB (Berkembang Sangat Baik ) 3 orang anak. Pada siklus III tidak ada satupun kriteria BB (Belum Berkembang) dan MB (Mulai Berkembang), kriteria BSH (Berkembang Sesuai Harapan) 2 orang anak dan kriteria BSB (Berkembang Sangat Baik) 6 orang anak.

Berdasarkan hasil penelitian yang telah dilakukan, dapat diketahui bahwa penggunaan media gambar seri menurut Madyawati (2016,hlm 208) "Media gambar seri yaitu urutan gambar yang mengikuti suatu percakapan dalam hal memperkenalkan atau menyajikan arti yang terdapat pada gambar." Dikatakan gambar seri karena gambar satu dengan gambar yang lain memiliki hubungan keruntutan peristiwa. Media gambar seri juga 
bisa meningkatkan pemahaman anak tentang metamorfosis yang terlihat dari setiap siklus yang mengalami peningkatan.

\section{KESIMPULAN}

Berdasarkan hasil penelitian yang ditemukan dilapangan tentang "pemahaman tentang metamorfosis melalui media gambar seri " di kelompok B TK Negeri Pembina Kota Tasikmalaya, dapat diperoleh kesimpulan sebagai berikut :

1. Kondisi objektif pemahaman anak di kelompok B TK Negeri Pembina yang masih belum berkembang dengan baik. Masih ditemukan anak-anak yang belum bisa menjawab ketika diberi pertanyaan oleh guru. Hasil observasi menunjukan bahwa pembelajaran masih menggunakan metode ceramah.

2. Kemampuan guru dalam merancang pelaksanaan pembelajaran harian (RPPH) tentang pemahaman tentang metamorfosis melalui media gambar seri, dilaksanakan dalam 3 siklus pembelajaran, setiap siklus terdiri dari 1 tindakan. Setiap tindakan diawali dengan perencanaan, pelaksanaan, pengamatan atau hasil observasi atau refleksi. Hal tersebut dibuktikan dalam peningkatan kemampuan guru dalam merancang RPPH setiap siklus yang meningkat, yaitu siklus I dengan rata-rata sebesar 2,66 kriteria baik, siklus II dengan rata-rata sebesar 3,04 kriteria sangat baik dan siklus III dengan rata-rata 3,53 kriteria sangat baik.

3. Pemahaman anak tentang metamorfosis melalui media gambar seri di Kelompok B TK Negeri Pembina mengalami peningkatan

\section{SARAN}

Berdasarkan penelitian yang telah dilakukan, maka peneliti menyararankan beberapa hal, diantaranya :

1. Masyarakat yang dalam hal ini orangtua, agar senantiasa menyadari pentingnya pemahaman tentang metamorfosis sebagai kesiapan memasuki pendidikan dasar

2. Guru-guru PAUD agar lebih menstimulus pemahaman tentang metamorfosis yang berorientasikan pada bermain

3. TK Negeri Pembina Kota Tasikmalaya dan sejenisnya agar lebih memperkuat pengembangan pemahaman anak tentang metamorfosis sejak dini khusunya dilingkungan sekolah yang berorientasikan pada bermain.

4. Orangtua anak usia dini, dapat menjadikan hasil penelitian ini sebagai masukan dalam mengembangkan pemahaman tentang metamorfosis yang disesuaikan dengan tahap usia anak ; dan

5. Peneliti selanjutnya agar melakukan pengembangan melalui penelitian yang lebih luas terkait pemahaman tentang metamorfosis melalui media gambar seri

\section{DAFTAR PUSTAKA}

AR, Syamsuddin. (2006). Metode Penelitian Bahasa. Bandung : PT Remaja Rosdakarya

Arikunto, S. (2013). Prosedur Penelitian. Jakarta : Rinekacipta

Devi, P. K. \& Anggraeni, S. (2008). Ilmu Pengetahuan Alam. Jakarta : Pusat Perbukuan 
Farndon, J \& Kirkwoond, A. (2011). The Little Animal Encylopedia. : Kingfisher

Hamdani, N.A \& Hermana, D. (2008). Classroom Action Research. Bandung : Rahayasa Resarch and Training

Holis, A. (2016). Belajar Melalui Bermain untuk Pengembangan Kreativitas dan Kognitif Anak Usia Dini. Jurnal Pendidikan Universitas Garut, IX, 23-27

Purto, S. D., Lestari, U., \& Lukiati, B. (2016). Pengembangan Buku Ajar Pengembangan Hewan Berbasis Penelitian Metamorfosis Ulat Sutera Bombyx Mori L. Jurnal Pendidikan : Teori, Penelitian dan Pengembangan, I, 1229-1234

Khadijah. (2015). Media Pembelajaran Anak Usia Dini. Medan : Buku Umum \& Perguruan Tinggi

Latif, M, dkk. (2013). Orientasi Baru Pendidikan Anak Usia Dini Teori dan Aplikasi. Jakarta : Prenadamedia Group

Madyawati, L. (2016). Strategi Pengembangan Bahasa Pada Anak. Jakarta: Preadamedia Group

Mara'at, S (2012). Psikologi Perkembangan. Bandung : PT Remaja Rosdakarya Bandung
Marsudi (2013). Meningkatkan Proses dan Hasil Belajar Model Inquiri dalam Pembelajaran Daur Hidup. (Artikel Penelitian). Universitas Tanjungpura Pontianak

Peraturan Menteri Pendidikan dan Kebı 84 Republik Indonesia. (2014). Kurikulum 2013 Pendidikan Anak Usia Dini. Jakarta : Depdikbud

Panut, H. (2006). Dunia Ilmu Pengetahuan Alam. Bogor : Yudhistira

Ridwan. (2009). Metode \& Teknik Menyusun Proposal Penelitian. Jakarta : Alfabeta

Sujiono, Y.N. (2013). Konsep Dasar Pendidikan Anak Usia Dini. Jakarta: PT Indeks

Sugiyono (2013). Metode Penelitian Pendidikan. Bandung : Alfabeta

Undang-undang Nomor 20 Tahun 2003 tentang Sistem Pendidikan Nasional 